\title{
ASSESSMENT OF LEVEL OF FORMAL EDUCATION ON PERCEIVED BEHAVIOURAL CONTROL AND CONSUMERS' PURCHASE INTENTION OF COUNTERFEIT APPAREL PRODUCTS IN TANZANIA
}

\author{
Sophia Mbura , Hawa Uiso and Saganga Kapaya \\ The Open University of Tanzania, Faculty of Business Management \\ http://doi.org/10.35409/IJBMER.2020.3210
}

\begin{abstract}
This study aimed at assessing the moderating effect of level of formal education on the relationship between perceived behaviour control and purchase intention of counterfeit apparel products. The research used cross-sectional design during data collection and involved a sample of 315 households in Dar es Salaam, Tanzania. The formulated hypotheses were tested by Structural Equation Modeling (SEM) using IBM SPSS Amos 23version. The findings indicated that perceived behaviour control had a significant and positive effect on purchase intention of counterfeit apparel products. The study also revealed that level of formal education did not moderate the relationship between perceived behavioural control and purchase intention of counterfeit apparel products in Tanzania. The findings suggested that less and highly educated consumers similarly hold perceived behaviour control. This implied that there is no significant difference between consumers with high and less level of formal education group on the effect of perceived behavioural control on purchase intention of CAPs. The study concluded that perceived behavioural control is the primary determinant of purchase intention of CAPs. The conclusion is also be made on moderating effect of level of formal education whereby both consumers with less level of formal education and consumers with the high level of education possess a reasonable degree of belief control in performing their behaviour. Therefore, this study recommended to apparel products manufacturers, marketer players and policymakers to understand the consumers' perceived behaviour control as principal determinants of purchase intention of counterfeit apparel products when developing anti-counterfeiting strategies.
\end{abstract}

Keyword: Counterfeit Apparel Products, EDM Theory, TPB, Level of Formal Education.

\section{INTRODUCTION}

Counterfeit business is regarded as a problem faced by many countries in the world, including both developed and developing countries due to an impact of status competition. (Bhatia, 2018; Chiu \& Leng, 2016; Harun, Mahmud, Othman, Ali \& Ismael, 2020; Jiang, Miao, Jalees \& Zaman, 2019; Priporas, Kamenidou, Kapoulas \& Papadopoulou, 2015). According to Othman et al. (2018), counterfeit products create a negative effect on the brand owners, national economies, consumers' welfare and government. Huran et al. (2020) reported that counterfeit products have a negative effect on the economy because counterfeit products enter the market as smuggled goods 


\section{International Journal of Business Management and Economic Review}

Vol. 3, No. 06; 2020

ISSN: 2581-4664

without proper tax payment. This is consistence with (Confederation of Tanzanian Industries CTI, 2017) which stated that counterfeit cause the government to lose tax revenue because of the smuggling activities. Fink et al. (2016), contends that counterfeiting is widely referred to as series of illicit activities that are associated with intellectual property rights (IPRs) infringement and is now becoming a common incident affecting a variety of industries and original products as well as the economies of countries.

The purchase of counterfeit products (CPs) is a serious global problem because it threatens economic, social and cultural issues of a specific country (Quoquab, Pahlevan, Mohammad \& Thurasamy, 2017). Previous researchers (Bhatia, 2018; Chui and Leng, 2016; Gani, Alam, Mostaquuim-Al-Islam, Chowdhury \& Faruq, 2019; Jiang et al., 2019; Kim \& Karpova, 2010; Lu, 2013; Pham \& Nasir, 2016; Quoquab et al., 2017; Stravinskiene, Dovaliene \& Ambrazeviciute, 2013) identified the factors influencing consumers' purchase intention and revealed inconsistent findings on the link between factors of CPs and purchase intention of the CPs.

In the same line, there are also disagreements among the researchers on how the demographic variables (age, education level, gender and income) influence consumers' purchase intention of CPs. The demographic variables can either be used as predictor variables or as moderator variables in examining consumers purchase intention to increase the explanatory power of the theory in predicting consumer purchase intention (Harun et al., 2020). This study is guided by the Theory of Planned Behaviour and Ethical Decision Making Theory to determine the relationship between perceived behavioural control and purchase intention. The Theory of Planned Behaviour by Ajzen (1991) indicated that perceived behavioural (PBC) control is one of the main determinants of behavioural intention. Therefore, the researcher used the level of formal education (LFE) as the moderating variable because its influence on the link between perceived behavioural control and consumers' purchase intention of CPs had not been well addressed thus, filling the theoretical gap. In Tanzania, counterfeit products have continued to flourish in the marketplace (CTI, 2017), and the studies which investigated the factors influencing consumers to either purchase or intention to purchase counterfeit products are still scarce (Mushi \& Noor, 2016). There are different types of counterfeits found in Tanzania markets. They include both locally manufactured counterfeits and imported counterfeit goods. The main counterfeits products found in the market, including electrical products, TV sets, apparel products (clothes), motor vehicle spare parts, mobile phones, medications and building materials (CTI, 2017).

In the present study, the researcher had an interest in studying counterfeit apparel products (CAPs) because apparel industry is observed to be number one in the industries affected by counterfeits manufacturers (Moon, Javid, Kiran, Awan, Farooq, 2018). Counterfeit apparel products cause the loss of genuine brand reputation and the loss of billions of US dollars to the economy every year (Moon et al., 2018). Additionally, counterfeits apparel products are among the popular CPs found in the Tanzania market (CTI, 2017). Besides that, there are a limited number of studies that used counterfeit apparel products in Tanzania (Lwesya, 2017; Mushi \& Noor, 2016).

Counterfeit apparel products refer to the copy of trademarked clothing, specifically the outerwear. Example of CAPs found in Tanzania market includes trousers (cadets and jeans), executive suits, bed sheets, T-shirts, sofa materials, women wrappers, towels and handkerchiefs 


\section{International Journal of Business Management and Economic Review}

Vol. 3, No. 06; 2020

ISSN: 2581-4664

(CTI, 2017). Many efforts have been made by anti-counterfeiting agents such as government, the original brand manufactures and other institutions to curb the problem of counterfeit business. However, still, there is an increase in the number of consumers of CPs in Tanzania (Fair Competition Commission, 2015). The studies conducted in Tanzania indicated different factors influencing purchase intention. However, all these studies did not take into consideration the role of the level of formal education as moderating variable in their analysis to assess the relationships between the variables thus the current study attempts to fill that gap. Level of formal education in this present study was referred to as the number of years that someone has spent in the school. Hence, the level of formal education as a moderating variable was expected to improve the relationships between perceived behaviour control and purchase intention of CAPs

\section{LITERATURE REVIEW}

\subsection{Theoretical Grounding}

According to $\mathrm{Lu}$ (2013), there are several theoretical frameworks which are used in the various consumer behaviours studies. The theoretical frameworks including Technological Acceptance Model - TAM (Methieson, 1991), Ethical Decision Making theory- EDM (Ferrel and Gresham (1985), The Expected Utility Theory -EUT (Schoemaker, 1982), Theory of Reasoned Action TRA (Fishbein \& Ajzen, 1975) and Theory of Planned Behaviour - TPB (Ajzen, 1991). However, TPB has been used in the prediction of consumer behaviour in many studies. TPB has the ability to predict consumers' intention to purchase of CPs which are observed by many scholars including Bhatia (2018); Chiu \&Leng (2016); Jinhwa (2009); Kim \& Karpova (2013); Lu (2013); Phau, I. Sequeira, M. \& Dix, S (2009) and Penz \& Stottinger (2005). Therefore, the researcher will bank on the idea of TPB to predict the consumers' behaviour towards counterfeit apparel products through examining the perceived behavioural control against purchase intention. Perceived behavioural control refers to a person's perception of the ease or difficulty of performing the behaviour of Ajzen (1991). Perceived behaviour control consists of a combination of the control factor and the perceived power of a particular control factor (Penz \& Stottinger, 2005). Thus, control beliefs refer to the perception of different control factors such as resources and opportunity that facilitate or impede the performance of the behaviour. On the other hand, perceived power refers to the likelihood that a controlling factor may prevent an individual from performing the behaviour.

Perceived behavioural control is the component which differentiates TRA and TPB in the sense that TRA believes that human behaviour is under volitional control and can be predicted by intentions only. Thus the inclusion of perceived behaviour control in TPB is to predict nonvolitional behaviours (Ajzen, 1991). However, there is inadequate of insights in the literature on how demographic factors, particularly education influences the purchase intention (Bhatia, 2018; Harun et al., 2020; Yoo \& Lee, 2012). Therefore, this study attempted to fill the gap. The researcher reviewed the theory of Ethical Decision Making (EDM) so as to come up with an additional variable related to demographic factors. EDM theory is also applied to predict purchase intention of CPs, which using factors somehow different from TPB factors such as education (Koklic, 2011). EDM provided the level of formal education variable that was deployed as a moderating variable in the relationship between perceived behavioural control and purchase intention, as suggested by Harun et al. (2020). This means that the extent to which how 


\section{International Journal of Business Management and Economic Review}

Vol. 3, No. 06; 2020

ISSN: 2581-4664

the level of formal education influences the perceived behavioural control under consumers with less level of formal education is a significant difference from the consumers with the high level of formal education (Moepswa, 2016). Therefore, it was expected that level of education positively moderates the relationship between the perceived behavioural control and purchase intention of CAPs.

\subsection{Empirical Grounding and Hypotheses Formulation}

2.2.1 Relationship between Perceived Behavioural Control and Purchase Intention of CAPs Ajzen (1991) defined perceived behaviour control as the perception of the ease or difficulty to perform the behaviour of interest (control beliefs). Kim \& Karpova (2010) indicated that the perceived accessibility of resources and opportunity might lead to behavioural intention and actual behaviour. Previous researchers have assessed the relationship between perceived behavioural control and purchase intention in a different context and provide inconsistent results. Cheng et al. (2011) conducted a study in China with the primary objective of examining consumers' intention to purchase CPs. The study composed of 400 sample size and SEM was used to test the relationships between the variables. The study findings suggested that purchase intention of CPs increases with PBC. The findings are in line with that of Penz \& Stottinger (2005) who conducted a study on an explanatory model for volitional purchase of CPs of Austrian consumers. The study revealed that $\mathrm{PBC}$ is positively related to the purchase intention of CPs.

Similarly, Mush \& Noor (2016) conducted a study to examine the consumer behaviour and counterfeit purchase in Tanzania, which also tested the relationships between PBC and purchase intention of CPs. The findings revealed that PBC positively influenced the purchase intention of CPs in Tanzanian consumers.

The findings are related to the findings obtained by previous scholars such as Kim \& Karpova (2010); Kwong, Yau, Lee, Sin \& Tse (2003) and Lu (2013) who also examined the relationship between PBC and purchase intention of CPs. Equally, the Chang (1998) found that PBC was the significant determinant of purchase intention of CPs of Hong Kong consumers. The findings are similar to the assumptions made by Ajzen (1991) that PBC is one of the determinants of purchase intention. However, a study conducted by Chiu \& Leng (2016) which aimed at comparing the purchase intention of CPs between Singapore and Taiwan consumers found that there is an insignificant relationship between PBC and purchase intention of CPs in Singapore consumers. Thus the findings are inconsistent with the assumptions made by Ajzen (1991), that PBC is a significant factor of purchase intention. Due to the inconsistent results between the previous scholars about the link between PBC and consumers' PI of CPs, thus call attention to conduct another study that provides a deeper understanding of the proposed relationship. Given the fact that previous researchers have tested the direct relationship between perceived behaviour control and purchase intention, and focusing on the idea that the relationship was indicated to be positive in the TPB. Thus, this study proposed the following hypothesis

$\mathrm{H} 1$ : There is a positive relationship between perceived behavioural control and purchase intention of counterfeit apparel products

2.2.2 The Moderation Role of the level of Education on the Relationship between Perceived Behavioural Control and Purchase Intention of Education is referred to as the collection of knowledge, values and beliefs (UNESCO, 2016). 


\section{International Journal of Business Management and Economic Review}

Vol. 3, No. 06; 2020

ISSN: 2581-4664

People acquire education through socialisation, for instance, in family, social groups and formal education. The formal education system, training programs, seminars and courses are related to ethics and facilitate ethical belief and behaviour (Faria, 2013; Ferrell \& Gresham, 1985). Level of formal education influences individual ability to understand and interpret unethical behaviour such as the purchase of CPs. Moepswa (2016) asserted that education level is inversely related to consumers' purchase intention towards CP. It was evident that highly educated people are less likely to engage in purchasing counterfeit than the less educated ones. This might be because consumers who are more educated can understand the risks associated with CPs and are more concerning about the ethical issues. Level of formal education is also expected to exert an effect on perceived behavioural control, the higher the level formal of education, the less the perceived behavioural control and purchase intention, as such the following hypothesis was formulated H2: Formal education level positively moderates the relationship between perceived behavioural control and consumers' purchase intention of counterfeit apparel products

\subsection{Conceptual Framework}

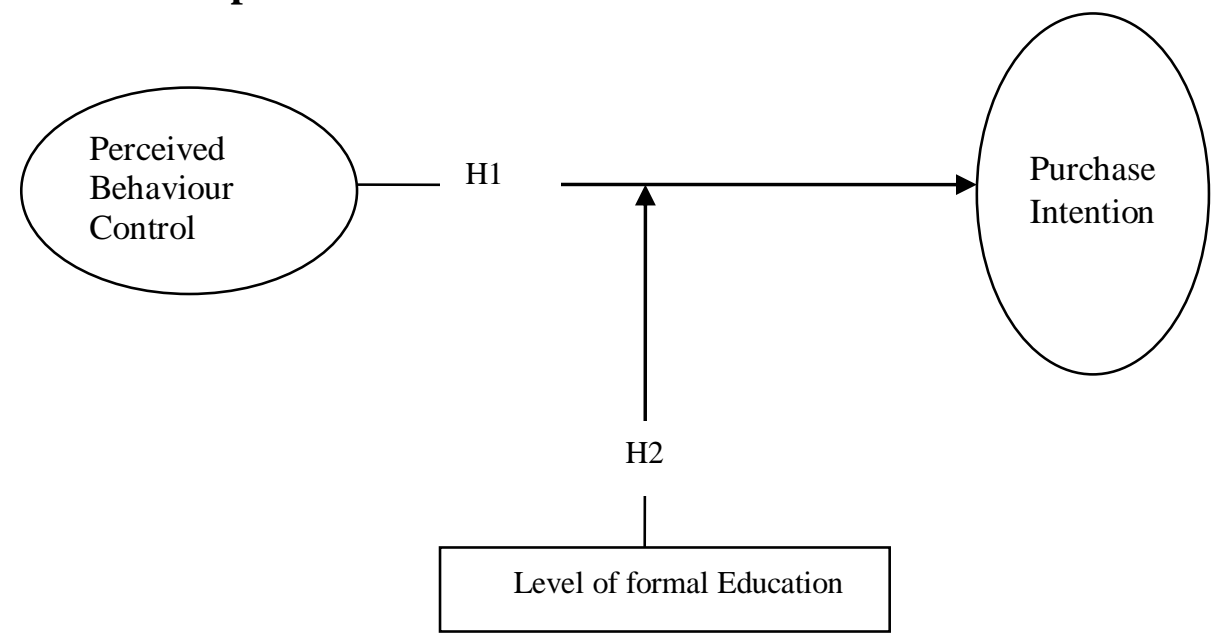

Figure 2.1: Conceptual Framework

Source: Researcher construction based on the synthesis of the literature (2020)

\section{MATERIALS AND METHODS}

\subsection{Targeted Population and Area of the Study}

The population of this study was consumers of apparel products in Dar es Salaam districts in Tanzania. Dar es Salaam is chosen because it is the major commercial city with a very high population compared to other regions of Tanzania (NBS, 2019). Currently, Dar es Salaam has 3.9 million, whereby 80 per cent of counterfeits products enter in Tanzania are through Dar es Salaam port. It also consists of 50 to 60 per cent of counterfeits products in the markets as compared to other regions of Tanzania (CTI, 2017). Thus, the selected population and study area resulted in useful analytical information to substantiate the relationship between perceived 


\section{International Journal of Business Management and Economic Review}

Vol. 3, No. 06; 2020

ISSN: 2581-4664

behaviour control and purchase intention of CAPs

\subsection{Sampling Procedure and Design}

In this study, the probability sampling procedure was carried out involving two probability techniques which are multistage and systematic sampling techniques. These procedures stressed in obtaining the representative sample that offers the generalization of quantitative study (Saunders, Lewis, \& Thornhill, 2012). According to National Bureau of Statistics (NBS, 2019) of Tanzania, Dar es Salaam consists of 462 streets with 915806 households. These streets helped to identify the households, and through that, respondents for the current research were obtained. Therefore, Multistage sampling technique was employed to divide the population into different stages in order to get selected streets, selected households and listing of households. On the other hand, a systematic sampling technique was also employed at the part of streets and household selection where sampling interval was calculated by taking a total number of households listed in a particular street divided by 15 numbers of fixed households. The 15 numbers of households were chosen because they were used by many Tanzania Demographic Housing Survey (TDHS) reports as yielded good results, save time and reduce cost

\subsection{Measurement Instrument and Data Collection}

A self-administered questionnaire procedure was utilized to collect primary data from the field. The process of data collection was assisted with two trained research assistants so as to capture a large amount of data at a minimum duration of time. According to Saunders et al. (2012), the questionnaire is the appropriate tool to be used for any quantitative study; thus, the researcher opted to use questionnaire during data collection. Questionnaires were structured, closed-ended questions which were administered to the chosen sample of respondents. The selected respondents were given a short introduction in which the questions and the purpose of the study were elaborated in order to provide relevant data when filling the questionnaire. The questionnaire involved two parts. The first part consisted of respondents profile questions, whereas the second part was composed of the different statements measuring variables of the study captured in seven-point Likert-like scale. The choice of the seven Likert-like scales was also supported by $\mathrm{Lu}$ (2013) as an appropriate scale to measure consumer behavioural intention studies. In this study, the statements for the specific variables were measured using seven Likert-like scales. At the same time, respondents profile questions were measured by nominal scale for easy identification of the subjects (Hair, Babin, Anderson \& Black, 2010). Therefore, 315 households' consumers of apparel products were involved during data collection in various districts, wards and streets of Dar es Salaam.

Only 301 questionnaires were returned and screened for missing data and outliers. After thoroughly examining the returned questionnaires missing values were found in the three (3) questionnaires. Three questionnaires which had missing values in the section of respondents basic profile where deleted. Thus, a list-wise technique was employed to delete the three questionnaires and remained with 298 complete cases for further data analysis. The deletion of the case with missing data was asserted by Tabachnick and Fidell, (2013). They stated that deletion of the cases of missing data is one the best techniques of dealing with missing data that were very few and missing completely at random 
International Journal of Business Management and Economic Review

Vol. 3, No. 06; 2020

ISSN: 2581-4664

3.4 Measurement Variables of the Study

\begin{tabular}{|c|c|c|c|c|c|}
\hline $\begin{array}{l}\text { Variabl } \\
\mathrm{e}\end{array}$ & $\begin{array}{l}\text { No. } \\
\text { of } \\
\text { Item } \\
\text { s }\end{array}$ & $\begin{array}{l}\text { Cod } \\
\text { e }\end{array}$ & Measurement Items & Measurement & Sources \\
\hline $\begin{array}{l}\text { Perceiv } \\
\text { ed } \\
\text { Behavi } \\
\text { our } \\
\text { Contro } \\
\text { l }\end{array}$ & 5 & PBC & $\begin{array}{l}\text { PBC1=Easy to } \\
\text { purchase } \\
\text { PBC2=Enough time } \\
\text { PBC3=Complete } \\
\text { control } \\
\text { PBC4=Decision } \\
\text { PBC5=Enough } \\
\text { information }\end{array}$ & $\begin{array}{l}\text { Seven point } \\
\text { scale } \\
\text { 1= strongly } \\
\text { disagree } \\
\text { 4= Neutral } \\
7=\text { Strongly } \\
\text { Agree }\end{array}$ & 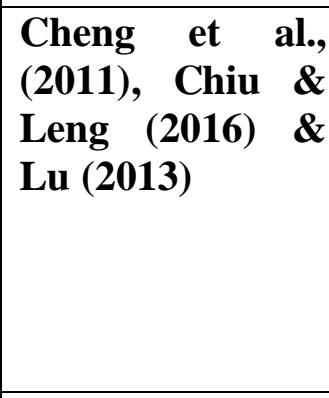 \\
\hline $\begin{array}{l}\text { Purcha } \\
\text { se } \\
\text { Intenti } \\
\text { on }\end{array}$ & 4 & PI & $\begin{array}{l}\text { PI1=Think as a } \\
\text { choice } \\
\text { PI2=Consideration } \\
\text { PI3=Recommendati } \\
\text { on } \\
\begin{array}{l}\text { PI4=Plan } \\
\text { purchase }\end{array}\end{array}$ & $\begin{array}{l}\text { Seven point } \\
\text { scale } \\
\text { 1= strongly } \\
\text { disagree } \\
\text { 4= Neutral } \\
7=\text { Strongly } \\
\text { Agree }\end{array}$ & $\begin{array}{l}\text { Bhatia (2018), de } \\
\text { Matos } \\
\text { al.,(2007), } \\
\text { Rizwan et al., } \\
(2014), \\
\text { Stumpf et } \quad \text { al., } \\
(2011)\end{array}$ \\
\hline $\begin{array}{l}\text { Level } \\
\text { of the } \\
\text { formal } \\
\text { Educat } \\
\text { ion }\end{array}$ & 2 & LFE & $\begin{array}{l}\text { LFE1=1yr to } \\
13 y e a r s \\
\text { LFE2=14years and } \\
\text { above }\end{array}$ & $\begin{array}{l}\text { Categorical } \\
\text { scale } \\
1=\text { low LFE } \\
2=\text { high LFE }\end{array}$ & $\begin{array}{l}\text { Moepswa (2016), } \\
\text { \& Talula (2012) }\end{array}$ \\
\hline
\end{tabular}

Source: Researcher's computation from Literature, 2020

\subsection{Data analysis}

To perform the descriptive analysis, the study used IBM Statistical Package for Social Scientists (SPSS) version 22, whereby frequencies, mean and percentage were used for discussion. The study also utilized IBM Amos software version 23 to run CFA, structural equation models and multi-group moderation. Structural Equation Modeling (SEM) involved two procedures which were measurement and structural models. In the measurement model, the validity and reliability of all variables were assessed while structural model tested the proposed hypotheses. The reasons as to why SEM was chosen among the other multivariate data analyses were its ability to estimate the measurement of errors in the parameters as compared to other multivariate procedure. It is also a comprehensive statistical approach for the relationship among observed and latent variables that are shown by multiple measures Hair et al. (2010). 


\section{International Journal of Business Management and Economic Review}

Vol. 3, No. 06; 2020

ISSN: 2581-4664

\section{STUDY RESULTS}

\subsection{Respondents Profile}

In this study, the respondents' profile analysis was necessary to improve the validity even though the main objective of the study was focused on determining the effect of perceived behavioural control on consumers' purchase intention towards counterfeits apparel products. Thus, take into account of such requirements, the researcher obtained the respondents' profile by including questions which captured respondents' demographic information. Therefore, descriptive analysis was done in order to capture general respondents' information and use the results in the proceeding discussion and conclusions.

\subsubsection{Distribution of Respondents by Age, Gender and Marital Status}

The sample included respondents' age as a critical profile only because it showed the experience, significant exposure and control of counterfeit products matters (Talula, 2012). The analysis indicated that respondents aged between 41 and 50 that reflecting the majority age of people who had enough life experience, economically active. The results also revealed that the good distribution of gender composed of $57.7 \%$ was males and $47.3 \%$ were females. Concerning marital status, majority of respondents were married, implying that they are matured enough and exchange different ideas as seen in table 4.1

\section{Table 4.1: Demographic Statistics for Age, Gender and Marital Status}

\begin{tabular}{|c|c|c|}
\hline & Frequency & Per cent \\
\hline \multicolumn{3}{|c|}{ Age(Years Old) } \\
\hline $18-30$ & 25 & 8.4 \\
\hline $31-40$ & 98 & 32.9 \\
\hline $41-50$ & 123 & 41.3 \\
\hline Above 50 & 52 & 17.4 \\
\hline \multicolumn{3}{|l|}{ Gender } \\
\hline Male & 157 & 57.7 \\
\hline Female & 141 & 47.3 \\
\hline \multicolumn{3}{|c|}{ Marital status } \\
\hline Single & 31 & 10.4 \\
\hline Married & 239 & 80.2 \\
\hline Divorced & 13 & 4.4 \\
\hline Widow & 9 & 3.0 \\
\hline Separated & 6 & 2.0 \\
\hline
\end{tabular}

Source: Field Data, 2020

\subsubsection{Distribution of Respondents by Level of Education}

With regard to respondents' level of education, the majority of the respondents were 121 who attained secondary education, followed by 74 gained first-degree educations. The detailed results about respondents' level education are shown in table 4.2. Respondents of different levels of education characterize the sample is evident that the information collected was relevant. This can 


\section{International Journal of Business Management and Economic Review}

Vol. 3, No. 06; 2020

ISSN: 2581-4664

be summed up by expressing that the respondents were capable and knowledgeable to respond to the questions in the research instrument.

Table 4.2: Respondents Level of Education

\begin{tabular}{|l|r|r|}
\hline & Frequency & Per cent \\
\hline Non- formal education & 1 & .3 \\
\hline Primary & 52 & 17.4 \\
\hline Secondary & 121 & 40.6 \\
\hline Diploma & 36 & 12.1 \\
\hline First degree & 74 & 24.8 \\
\hline Masters degree & 13 & 4.4 \\
\hline PhD degree & 1 & .3 \\
\hline Total & 298 & 100.0 \\
\hline
\end{tabular}

Source: Field Data, 2020

\subsubsection{Distribution of Respondents by Occupation}

The results indicated that business people accounted for $48.0 \%$, which occupies the majority of the respondents in the sample. The employees constituted for $46.6 \%$, and $1 \%$ were for students as well as unemployed respondents comprised of $4.4 \%$. This indicates that more people in Dar es Salaam region fall in the category of employed or business operators reflecting the characteristics of the people living in big cities. Table 4.3 demonstrates the respondents' occupation

\section{Table 4.3: Respondents Occupation}

\begin{tabular}{|c|r|r|}
\hline & Frequency & \multicolumn{2}{|c|}{ Per cent } \\
\hline Employees & 139 & 46.6 \\
\hline Business & 143 & 48.0 \\
\hline Students & 3 & 1.0 \\
\hline Unemployed & 13 & 4.4 \\
\hline Total & 298 & 100.0 \\
\hline
\end{tabular}

Source: Field Data, 2020

\subsection{Measurement Model Analysis}

In this present study, the measurement models were tested using a Confirmatory Factor Analysis (CFA). IBM Amos version 23 was used in the initial CFA run. CFA is generally motivated by the theoretical relationship to exist between observed and unobserved variables. According to Hair et al., (2010), the researcher could be able to assess the contribution of every scale item that showed the extent of the reliability of the scale in measuring based on the unobserved construct. Thus, all the constructs were put to CFA for validity and reliability assessment. The constructs were also checked to ensure there is an absence of multicollinearity. To assess how well the hypothesized model fits the data, various goodness of fit indices were established such as the Goodness of Fit Index (GFI), the Adjusted Goodness of Fit Index (AGFI), the Root Mean Square Error of Approximation (RMSEA), the ratio of chi-squire with respect to the degree of freedom 


\section{International Journal of Business Management and Economic Review}

Vol. 3, No. 06; 2020

ISSN: 2581-4664

$\mathrm{x} 2 / \mathrm{df}$, the Tucker Lewis Index (TLI), the Comparative Fit Index (CFI) and the p-value. Hooper et al. (2008) suggested that there is no basic rule in assessing model fit. However, it is good to provide a report on various indices because different indices express each aspect of the model fit.

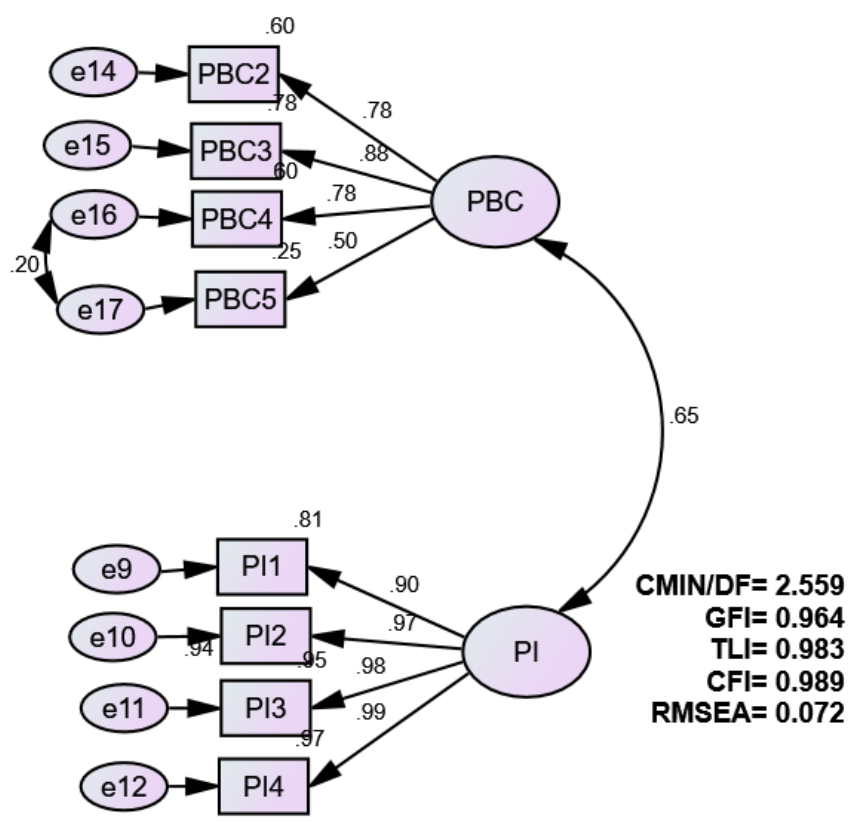

Figure 4.1: Measurement Model

Source: Field Data, 2020

\subsubsection{Factor Loadings}

Hair et al. (2010) recommended that the values of the factors loading should at least achieve a minimum of 0.5 values. Yong and Pearce (2013) stressed on the idea that all factors should meet the cutoff point of 0.5 and above to justify the occurrence of significant factor loading and good reliability of the factors. Basing on the criteria proposed by Hair et al. (2010) and Yong and Pearce (2013), all the factors for this study had obeyed the suggested criteria hence they can be applied in the further analysis. The results also indicated that the model had fit well to the data as all the selected good fit indices attained the criteria recommended by Awang (2011) as figure 4.1

\subsubsection{Reliability Results}

The internal consistency using the Cronbach's alpha value was used to test the number of indicator items of a specific factor. Subsequently, composite Reliability (CR) employing values of $\mathrm{CR}$ was used to measure the latent variables of this study. The results indicated that Cronbach's alpha values for all items were more than 0.7, and the values of C.R were above 0.5 as shown in table 4.3 , proving the achievement of reliability of the data.

\subsection{Convergent Validity Test Results}

Convergent validity was based on the notion that a test should be similar to the construct it is 


\section{International Journal of Business Management and Economic Review}

Vol. 3, No. 06; 2020

ISSN: 2581-4664

supposed to measure. Convergent validity was observed in the measurement model at the point where all the items reached the level of statistical significance (Ahmad et al., 2016). To ensure convergent validity, Hair et al. (2010) recommended that any item loading at the measurement model should have at least 0.5 that expressed at least $30 \%$ of the variance in the variable.

Under this study, all the loadings attained the recommended thresholds values proposed by (Hair et al., 2010), as shown in figure 4.3. Besides, Fornell and Larcker (1981) proposed the recommendation of using Average variance extracted (AVE) to test the convergent validity of the model. Thus, the researcher computed the AVE for every construct employing the formula provided by Awang (2011) in the excel spreadsheet. Table 4.3 indicated the results of calculated AVE values.

The AVE formula used

$\mathrm{AVE}=\Sigma \lambda^{2} / \mathrm{n}$

Where $\lambda=$ factor loading of every item and $n=$ number of items in the model

Table 4.3: Reliability and Convergent Validity

\begin{tabular}{|l|l|l|l|}
\hline Construct & $\begin{array}{l}\text { Cronbach's } \\
\text { alpha value }\end{array}$ & $\begin{array}{l}\text { Composite } \\
\text { Reliability }(\text { CR) }\end{array}$ & $\begin{array}{l}\text { Average Variance } \\
\text { Extracted (AVE) }\end{array}$ \\
\hline $\begin{array}{l}\text { Perceived } \\
\text { Behavioural Control }\end{array}$ & 0.855 & 0.828722 & 0.55643 \\
\hline $\begin{array}{l}\text { Purchase Intention } \\
\text { (PI) }\end{array}$ & 0.977 & 0.979501 & 0.92285 \\
\hline
\end{tabular}

Source: Field Data, 2020

\subsubsection{Discriminant Validity}

Discriminant validity is an indication of low correlation among the latent variables (Bhattacherjee, 2012). In this study, the discriminant validity was assessed by the use of comparison between the square root of the average variance extracted (AVE) and correlation of latent constructs as recommended by Fornell-Lacker (1981). Awang (2011) purported that the discriminant validly is achieved under this approach when the AVE estimates were higher than the squared correlation estimates of the constructs as indicated in 4.4

Table 4.4: Discriminant Validity

\begin{tabular}{|l|l|l|}
\hline Construct & $\begin{array}{l}\text { Perceived } \\
\text { Behavioural Control }\end{array}$ & $\begin{array}{l}\text { Purchase Intention } \\
\text { (PI) }\end{array}$ \\
\hline $\begin{array}{l}\text { Perceived } \\
\text { Behavioural Control }\end{array}$ & $\mathbf{0 . 7 4 5 9 4 2}$ & \\
\hline $\begin{array}{l}\text { Purchase Intention } \\
\text { (PI) }\end{array}$ & -.625 & $\mathbf{0 . 9 7 9 5 0 1}$ \\
\hline
\end{tabular}

Source: Field Data, 2020

\subsubsection{Multicollinearity Test Results}

The presence of multicollinearity was assessed by the Variance Inflated Factor (VIF). Hair et al. 


\section{International Journal of Business Management and Economic Review}

Vol. 3, No. 06; 2020

ISSN: 2581-4664

(2010), recommended the values of VIF to be less than 5, thus in this study, the values of VIF for independent variables were less than 5, indicating no issues of multicollinearity as seen in table 4.5. Nevertheless, the values of VIF are also used to communicate the absence of Common Method Bias $(\mathrm{CMB})$. The results indicated VIF values $<3$ which implied that the variables are free from CMB as recommended by Kock (2015)

\section{Table 4.5: Multicolliniearity- Variance Inflated Factor (VIF)}

\begin{tabular}{|l|l|}
\hline Construct & VIF \\
\hline $\begin{array}{l}\text { Perceived } \\
\text { Behavioural Control }\end{array}$ & 1.182 \\
\hline & \\
\hline & Dependent Variable: PI \\
\hline
\end{tabular}

Source: Field Data, 2020

\subsection{Hypothesis Testing Results}

The structural model was employed to test the hypothesized relationship between the variables. The formulated hypotheses for this study were tested based on Structural Equation Modeling (SEM) approach. Different coefficients and scores obtained from the structural model analysis were used to assess the relationship between the variables. The results of the structural model revealed a positive and significant effect of perceived behavioural control on consumers' purchase intention of CAPs $(\gamma=0.65, \mathrm{p}<0.05)$ which supported the proposed hypothesis. Hence, $\mathrm{H} 1$ was accepted as exhibited in figure 4.2

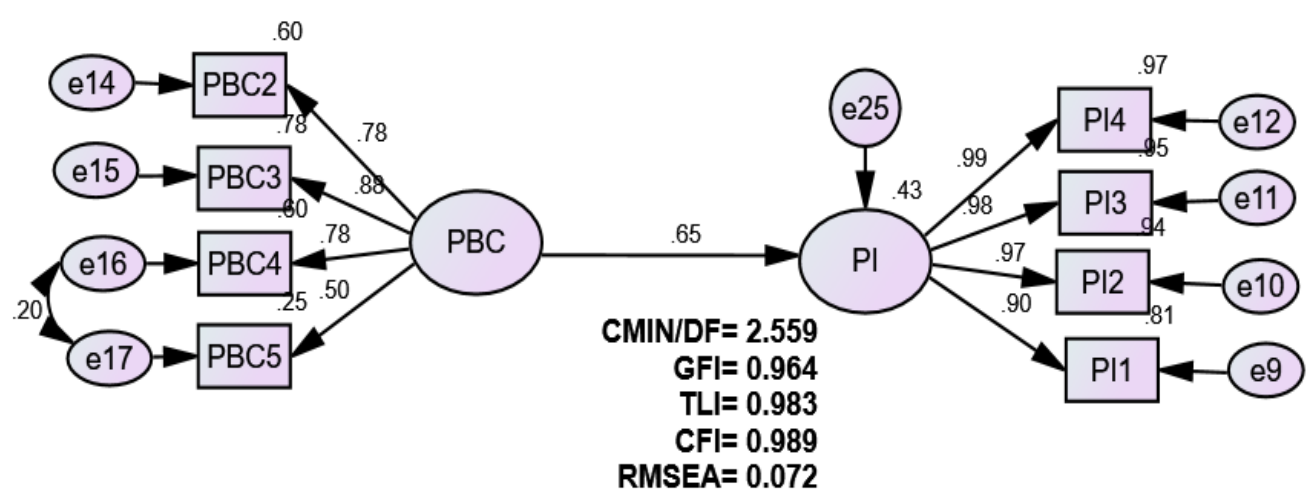

Figure 4.2: Structural Model

Source: Field Data, 2020

\subsection{Multi-group moderation Results}

Moderating effects of level of education was assessed in this study whereby the sample was divided into the less and high level of education groups. The results of the multi-group analysis revealed the results of chi-square difference test using IBM AMOS 23 which indicated that the two models were not different in terms of the less education level and high education level 
International Journal of Business Management and Economic Review

Vol. 3, No. 06; 2020

ISSN: 2581-4664

groups $(\mathrm{p}<0.01)$ as shown in 4.6

Table 4.6: The Effect of PBC on PI for Less and High Level of Formal Education

\begin{tabular}{|l|c|c|l|}
\hline & Standardized Estimate & $\mathbf{P}$ & Result \\
\hline $\begin{array}{l}\text { Less Level of } \\
\text { Formal Education }\end{array}$ & .470 & $* * *$ & Significant at $\mathrm{p}=0.000$ \\
\hline $\begin{array}{l}\text { High Level of } \\
\text { Formal Education }\end{array}$ & .428 & $* * *$ & $\begin{array}{l}\text { Significant at } \\
\mathrm{p}=0.000\end{array}$ \\
\hline
\end{tabular}

Source: Field Data, 2020

From table 4.6, the standardized parameter estimate for the less level of formal education group was .470 , and for the high-level formal education group, the standardized estimate was .428 . This indicated that parameter estimates were significant in both the less and high level of formal education groups. Basing on moderation analysis results, it was noted that the level of formal education did not moderate the relationship between PBC and PI of CAP. Still, the relationship between PBC and PI is stronger in less level of formal education group than in the high level of the formal education group. Therefore, it can be concluded that there was a presence of partial moderation, implied that the effect is of a very negligible significant amount of PBC on PI; as such H6 was not supported

\section{DISCUSSION OF THE RESEARCH FINDINGS}

This study aimed to assess the moderating effect of level of formal education on the relationship between perceived behavioural control and purchase intention of counterfeit apparel products in Tanzania. The results indicated that perceived behavioural control was positively related to purchase intention $(\gamma=0.65 ; \mathrm{p}=0.000$ shown in figure 4.2). The positive relationship helped to establish the fact that the greater the perceived behaviour control the more purchase intention of CAPs, thus motivating consumers to have strong purchase intention of CAPs. This provides consistent results with the TPB. The findings of this study were also consistent with findings obtained by Cheng et al. (2011), Kwong, et al. (2003), Mushi \& Noor (2016), Lu (2013), Kim \& Karpova (2010), Penz \& Stottinger (2005), Riquelme et al. (2012) and Ting et al. (2016). They revealed a significant positive relationship between PBC and PI. The findings indicated that when perceived behaviour control increases the more the purchase intention increases and the vice versa. However, the observed behaviour control influenced purchase intention when the behaviour is not in the complete volitional control ( $\mathrm{Lu}, 2013)$. This is because the studies in the context of counterfeit are in illegal business; the consumers' behaviour is customarily under no complete control. The counterfeits products are sold parallel with genuine products through many channels such as retail shops, supermarkets, online shopping and street vendors. Therefore, in this case, perceived behavioural control plays a crucial role in influencing purchase intention. However, the findings differ with the findings indicated by Chiu \& Leng (2016) in Singapore, who found that perceived behaviour control was not a significant factor in purchasing intention. The reason for the difference of the findings being that there is a strong relationship existing between perceived behaviour control and purchase intention, the studied population, the context as well as the selected product category. Therefore, Perceived behavioural control changes 


\section{International Journal of Business Management and Economic Review}

Vol. 3, No. 06; 2020

ISSN: 2581-4664

depending on situations and actions, which leads a person to have different perceptions of behavioural control based on the situation

However, the findings confirmed that the level of formal education did not moderate the relationship between perceived behavioural control and purchase intention of CAPs. The findings suggested that less and highly educated consumers hold perceived behaviour control in a similar way. This showed that there is no significant difference between high and less group of consumers in terms of the relationship between perceived behavioural control and purchase intention of CAPs. Evidence showed that consumers with a high level of formal education possess some degree of resisting the temptation in performing actions which were influenced by their behaviour (Lu, 2013). Most importantly perceived behavioural control could be viewed in the literature to have both internal control and external control types (Chui \& Leng, 2016). With internal control, individuals were assumed to have adequate knowledge, abilities, skills and some discipline embedded when performing the behaviour. In external control, individuals considered the approval of peers and referent groups to influence them into coming up with a positive attitude towards the behaviour. The external control includes information patterning to counterfeits, the ability to solve challenges they encountered when purchasing product and time needed to access counterfeit products, reflecting the high behaviour level of formal education consumer (Chui \& Leng, 2016; Lu, 2013). In connection to the theoretical contribution, the LFE in relation to perceived behaviour control and purchase intention of CAPs had not exerted effect since there is no difference in the significance levels between the two groups, as such the strength of the relationship between PBC and PI in TPB remained as it was is for both groups. This is because both less and high level of formal educated consumers does not seems to perceive PBC differently.

\section{CONCLUSION AND RECOMMENDATIONS}

The study concluded that perceived behavioural control had a positive and significant effect on purchase intention of CAPs. The great perceived behavioural controlled to high purchase intention of CAPs. Hence, perceived behavioural control is the primary determinant of purchase intention of CAPs. With respect to the moderation effect on the relationship between perceived behaviour control and purchase intention of CAPs, the results proved that level of formal education had no effect. This indicated that both less and high level of formal education consumers groups holds the same way the perceived behaviour control of CAPs. This revealed that both groups of consumers (less and high) level of formal education possesses a good degree of belief control in performing their behaviour. In summing up the conclusion, it can be said that this study has adopted some factors to examine the consumers' purchase intention of counterfeit apparel products in Tanzania. Even though counterfeits purchase and consumption are among the challenges that have been expanding broadly in both developing and developed countries, the previous studies put much attention to the developed countries than in developing countries. Hence, the present study has found a few fundamental insights based on the demographic factor (level of formal education) that were not captured within the past research conducted on counterfeit apparel products in Tanzania. Hence the study recommended that original of apparel products manufacturers, marketer players and policymakers should understand the consumers' perceived behaviour control as principal determinants of purchase intention of CAPs to assist 


\section{International Journal of Business Management and Economic Review}

Vol. 3, No. 06; 2020

ISSN: 2581-4664

them when developing anti-counterfeiting strategies

\section{REFERENCES}

Ahmad, N., Yousif, M., Shabeer, K. and Imran, M. (2016). A comprehensive model on consumers purchases intention towards counterfeit Mobiles, Pakistan. TextRoad Publication. 4(5), 131- 140

Ajzen, I. (1991). The theory of planned behaviour. Organisational behaviour and human decision processes, $50(2), 179-211$

Awang, Z. (2011). A Handbook on SEM: Structural Equation Modelling $2^{\text {nd }}$ ed. Kelantan: Universiti Teknologi MARA.

Bhatia, V. (2018). Examining consumers' attitude towards the purchase of counterfeit fashion products. Journal of Indian Business Research, (2), 193-207.

Bhattacherjee, A. (2012). Social Science Research: Principles, Methods, and Practices, (2nd ed.), Florida: Global Text Project.

Chang, M.K. (1998). Predicting unethical behaviour: A comparison of the theory of reasoned action and the theory of planned behaviour. Journal of Business Ethics, 17(16), 1825-1834.

Cheng, S. Hwai-Hui, F.and Tu, L. T. C. (2011). Examining customer purchase intentions for counterfeit products based on a modified theory of planned behaviour. International Journal of Humanities and Social Science, 1 (10), 278-284.Chiu, W. \& Leng, H. K. (2016) "Consumers' intention to purchase counterfeit sporting goods in Singapore and Taiwan. Asia Pacific Journal of Marketing and Logistics, 28(1), 23-36CTI (2017). The State of Counterfeit Goods in Tanzania. A Report prepared by the Confederation of Tanzanian Industries (CTI).

Fair Competition Commission (2015). Annual report.

Faria, A. (2013). Consumer Attitudes towards counterfeit goods: The case of Canadian and Chinese Consumers. A thesis for the award for the degree of Master of Science in Marketing and Consumer Studies at Guelph, Ontario, Canada

Ferrell, O. C. and Gresham, L. G. (1985). A contingency framework for understanding ethical decision making in marketing. Journal of Marketing, 49(3), 87-96

Fishbein, M. and Ajzen, I. (1975). Belief, attitude, intention, and behaviour: An Introduction to Theory of Research, Reading. MA: Addison, Wesley

Fornell, C. and Larcker, D.F. (1981). Evaluating structural equation models with unobservable variables and measurement error. Journal of Marketing Research. 18 (1), 39-50.

Gani, O. M, Alam, I. M, Al-Islam, M, Chowdhury A. S. and Faruq, M. O. (2019).Factorsaffecting consumers' purchase intention for counterfeit luxury goods in Bangladesh.Innovative Marketing, 15 (4)

Hair, J. F, Babin, J. B., Anderson, R.E. and Black, C.W. (2010). Multivariate data analysis. ( $7^{\text {th }}$ edition). Upper Saddle River: Pearson Prentice Hall

Harun, A., Mahmud, M., Othman, B., Ali, R and Ismael, D. (2020). Understanding experienced consumers towards repeat purchase of counterfeit products: The mediating effect of attitude. Management Science Letters, 10(1), 13-28

Hooper, D, Coughlan, J. and Mullen, M. R. (2008). Structural Equation Modelling: Guidelines for Determining Model Fit. The Electronic Journal of Business Research Methods, 6 (1), 53-60. Jiang, Y., Miao, M., Jalees, T. and Zaman, S.I. (2019), "Analysis of the moral mechanism to purchase counterfeit luxury goods: evidence from China", Asia Pacific Journal of Marketing and 


\section{International Journal of Business Management and Economic Review}

Vol. 3, No. 06; 2020

ISSN: 2581-4664

Logistics, 31 (3), 647-669

Kim, H. and Karpova, E. (2013). Consumer attitudes toward fashion counterfeits: application of the theory of planned behaviour. Clothing and Textile Research Journal, 28(2), 79-94.

Koklic, M.K. (2011). Non- Deceptive counterfeiting purchase behaviour: Antecedents of attitudes and purchase intentions. Journal of Applied Business Research, 27(2), 127-137.

Kwong, K. K., Yau, H. M., Lee, S.Y., Sin, Y.M. and Tse, C.B. (2003). The effects of attitudinal and demographic factors on intention to buy pirated CDs: The case of Chineseconsumers", Journal of Business Ethics, 47, 223-235.

Lee, J. M.S. (2009). Apparel, textiles and merchandising, Understanding college students purchase behaviour of fashion counterfeits: Fashion consciousness, Public self-consciousness, Ethical obligation, Ethical judgment, and the Theory of Planned

Behaviour. A thesis for the award of Bachelor degree at Ohio University, the faculty of theCollege of Health and Human Services, U.S.

$\mathrm{Lu}$, M. (2013). An investigation of consumers motives to purchase counterfeit luxury brandedproducts, Masters of Research Thesis, University of Wollongong, Australia

Lwesya, F. (2017). Factors influencing the marketability of counterfeit and pirated products in Dar-Es-Salaam Region, Tanzania: A factorial analysis. Saudi J. Humanities Soc. Sci, 2(1), 95105.

Mathieson, K. (1991). "Predicting User Intentions: Comparing the Technology Acceptance Model with the Theory of Planned Behavior." Information System Research, 2(3), 173-191.

Moepswa, M. T. (2016). The threat of counterfeit devices: complicity vs vigilance. The journal of business research and management, 7 (1).

Moon, M. A., Javaid, B., Kiran, M., Awan, M. H. and Farooq, A. (2018). Consumer perception of counterfeit clothing and apparel products attributes. Marketing Intelligence and planning. 36(7), $794-808$

Mushi, M. H. and Noor, M. A. N. (2016). Consumer behaviour and counterfeit purchase in the Tanzanian mainland. IPBJ, 8(1), 49-64

My Pham, T. and Nasir, M. A. (2016). Conspicuous Consumption, Luxury Products and Counterfeit Market in the UK. The European Journal of Applied Economics, 13 (1), 72-83

NBS (2019).National Statistical Survey, Dar es Salaam, Tanzania

Phau, I., Sequeira. M. and Dix, S. (2009). Consumers willingness to knowingly purchase counterfeit products: Direct marketing. An international Journal, 3(4), 262-281.

Penz, E. and Stottinger, B. (2005). Forget the real thing - take the copy: A explanatory model forthe volitional purchase of counterfeit products. Advances in Consumer Research, (32), 568-575 Riquelme, E. H., Abbas, S. M. E. \& Rios, E. R. (2012). Intention to purchase fake products in the Islamic country. Education business and society: contemporary Middle Eastern issues, 5(1), 6-22 Priporas, C., Kamenidou, I., Kapoulas, A. and Papadopoulou, F . (2015). Counterfeit purchase typologies during an economic crisis. European Business Review, 27 (1), 2-16.

Quoquab, F., Pahlevan, S., Mohammad, J. and Thurasany, R. (2017). Factors affecting consumers' intention to purchase counterfeit products: an empirical study in the Malaysian market. Asia Pacific Journal of Marketing and Logistics, 29(4), 837-853.

Saunders, M., Lewis, P. and Thornhill, A. (2012). Research methods for business students $\left(6^{\text {th }}\right.$ ed.). England: Harlow Pearson Educational Limited.Schoemaker, J. H .P. (1982). The expected utility model: its variants, purposes, evidence and 


\section{International Journal of Business Management and Economic Review}

Vol. 3, No. 06; 2020

ISSN: 2581-4664

limitations. Journal of Economic Literature, 20(2), 529-56

Stravinskiene, J., Dovaliene, A. and Ambrazeviciute, R. (2013). Factors influencing intent to buy counterfeits of luxury goods. Economics and Management, 18(4), 761-768.

Tabachnick, B. G. and Fidell, L. S. (2013). Using Multivariate Statistics. 6 ${ }^{\text {th: }}$ Pearson Education.

Tulula, M. J. (2012). The Demand for counterfeit goods in Kenya: A case study of mobile phones. The University of Nairobi Kenya. The research project for award of masters degree of Arts and Economics at the University of Nairobi, Nairobi, Kenya

UNESCO. (2016). Study Manual, available at http://uis.unesco.org/site/default/files/document/uoe2016manual_11072016_0.pdf

Yong, A. G. and Pearce, S. (2013). A beginner's guide to factor analysis: Focusing on exploratory factor analysis. Tutorials in Quantitative Methods for Psychology, 9(2), 79-94

Yoo, B. and Lee, S. H. (2012). Asymmetrical effects of past experiences with genuine fashion luxury brands and their counterfeits on purchase intention of each. Journal of Business Research, 65(10), 507-1515 